\title{
Sedentary subjects have higher PAl-1 and lipoproteins levels than highly trained athletes
}

\author{
Fabio S Lira', Jose C Rosa ${ }^{1}$, Adriano E Lima-Silva², Hélio A Souza ${ }^{3}$, Erico C Caperuto ${ }^{3}$, Marília C Seelaender ${ }^{3}$, \\ Ana R Damaso ${ }^{4}$, Lila M Oyama ${ }^{4}$, Ronaldo VT Santos ${ }^{4 *}$
}

\begin{abstract}
Physical exercise protects against the development of cardiovascular disease, partly by lowering plasmatic total cholesterol, LDL-cholesterol and increased HDL-cholesterol levels. In addition, it is now established that reduction plasmatic adiponectin and increased C-reactive protein (CRP) and plasminogen activator inhibitor-1 (PAI-1) levels play a role in the maintenance of an inflammatory state and in the development of cardiovascular disease. This study aimed to examine plasma lipid profile and inflammatory markers levels in individual with sedentary lifestyle and/or highly trained athletes at rest. Methods: Fourteen male subjects (sedentary lifestyle $n=7$ and highly trained athletes $n=7)$ were recruited. Blood samples were collected after an overnight fast $(\sim 12 \mathrm{~h})$. The plasmatic lipid profile (Triglycerides, HDL-cholesterol, LDL-cholesterol, total cholesterol, LDL-oxidized and total cholesterol/HDL-c ratio), glucose, adiponectin, C - reactive protein and PAI-1 levels were determined. Results: Total cholesterol, LDLcholesterol, TG and PAl-1 levels were lower in highly trained athletes group in relation to sedentary subjects ( $p<$ 0.01). In addition, we observed a positive correlation between PAI-1 and total cholesterol $(r=0.78 ; p<0.0009)$, PAI1 and LDL-c $(r=0.69 ; p<0.006)$ and PAl- 1 and TG levels $(r=0.56 ; p<0.03)$. The plasma concentration of adiponectin, CRP, glucose, HDL-cholesterol and total cholesterol/HDL-c ratio levels were not different. These results indicate that lifestyle associated with high intensity and high volume exercise induces changes favourable in the lipid profile and PAl-1 levels and may reduce risk cardiovascular diseases.
\end{abstract}

\section{Introduction}

The several studies have consistently shown that low levels of plasmatic high-density lipoprotein (HDL) and high levels of low- and very low-density lipoprotein (LDL and VLDL, respectively) are linked with a sedentary lifestyle and are strong predictor to cardiovascular disease [1-5]. In addition, many of these diseases associated to sedentary lifestyle are also characterized by alterations in pro-inflammatory markers in the plasma $[6,7]$. These inflammatory process include increase in plasma the pro-inflammatory cytokines as tumor necrosis factor alpha (TNF- $\alpha$ ), plasminogen activator inhibitor type-1 (PAI-1), C-reactive protein (CRP), interleukin 6 (IL-6) and reduction of anti-inflammatory cytokines as interleukin 10 (IL-10) and adiponectin [8-11].

\footnotetext{
*Correspondence: lira@unifesp.br; ronaldo.thomatieli@unifesp.br 'Department of Physiology, Division of Nutrition Physiology, Federal University of Sao Paulo, Brazil

${ }^{4}$ Department of Bioscience, Baixada Santista Campus, Federal University of São Paulo, Brazil
}

(c) 2010 Lira et al; licensee BioMed Central Ltd. This is an Open Access article distributed under the terms of the Creative Commons

The plasmatic PAI-1 and CRP levels are also strongly related to cardiovascular risk factors, increasing its levels leading of arising the hypertension, high triglyceride levels and likely obesity [6,12-16]. It is now established that reduction in the plasma to adiponectin and increased PAI-1 and CRP levels play a role in the maintenance of an inflammatory state and in the development of cardiovascular disease [4]. However, it is much less known if these pro- and anti-inflammatory markers are related to the lipoproteins and cholesterol levels in plasma. While competitive exercise training programs (characterized by moderate/high intensity and long duration) seem to reduce the LDL and total cholesterol and to increase the HDL concentration, evicting the progression or appearance of inflammatory atherosclerotic process [6], it remains slightly unknown if highly trained athletes have lower pro-inflammatory and higher anti-inflammatory markers than sedentary subjects.

Therefore, the objective of this study was to compare plasma levels adiponectin, PAI-1, CRP, and lipoprotein fractions between sedentary subjects and highly trained 
athletes. We hypothesised that individuals that performed high amount of exercise (moderate/high intensity and long duration) have improved lipid profile and inflammatory factors levels in relation sedentary subjects.

\section{Methods}

\section{Subjects}

Fourteen healthy men and non-smoking participated in this study. The subjects were sedentary lifestyle $(n=7)$ [age $28.6(6.9)$ years, height $174.0(0.04) \mathrm{cm}$, weight 75.6 $(10.2) \mathrm{kg}]$ and highly trained athletes in cycling $(\mathrm{n}=7)$ [age $29.8(5.7)$ years, height $177.0(0.06) \mathrm{cm}$, weight 74.7 (4.4) $\mathrm{kg}$. The anthropometric parameters (height and body weight) were measured and standardized using Lohman's protocol [17]. The physical and training characteristics of both groups are described in Table 1. The benefits and risks were explained before written consent was obtained. The study procedures were previously approved by the Ethics Committee of the Federal University of São Paulo. Non-inclusion criteria were: identified genetic, metabolic or endocrine disease, previous drug utilization, time exercise training program or nonexercise.

$\mathrm{VO}_{2 \max }$ test was performed of athletes in particular clinics. The data was sending for us analyzed. All data frequence, volume and intensity exercise were related by technical professional this athletes. The athletes remain $48 \mathrm{~h}$ without exercise.

\section{Blood sampling and analysis}

A catheter was inserted in a brachial vein for drawing venous blood samples. The blood samples $(10 \mathrm{ml})$ were immediately transferred into two 5 -ml vacutainer tubes (Becton Dickinson, BD, Juiz de Fora, MG, Brazil) containing EDTA for plasma separation. The tubes were centrifuged at $3000 \mathrm{~g}$ for 15 minutes at $4{ }^{\circ} \mathrm{C}$, and plasma samples were stored at $-80^{\circ} \mathrm{C}$ until analysis. Triglycerides, HDL cholesterol, and total cholesterol were assessed through commercial enzymatic kits (Labtest ${ }^{\circ}$,

Table 1 The height, body mass, and body mass index the both groups and the weekly exercise intensity, frequence, volume and time experience by highly trained athletes group.

\begin{tabular}{lcc}
\hline Subjects & Sedentary & Highly Trained Athletes \\
\hline Height $(\mathrm{cm})$ & $174 \pm 0.05$ & $177 \pm 0.06$ \\
\hline Body mass $(\mathrm{kg})$ & $75.6 \pm 10.2$ & $74.7 \pm 4.46$ \\
$\mathrm{BMI}\left(\mathrm{kg} / \mathrm{m}^{2}\right)$ & $24.9 \pm 2.54$ & $23.9 \pm 1.54$ \\
\hline Experience exercise training (years) & $8.86 \pm 2.73$ \\
Frequence exercise (time for week) & $4.43 \pm 1.27$ \\
Volume exercise (hours for day) & $2.14 \pm 0.62$ \\
Intensity exercise $\left(\mathrm{VO}_{\text {2max }}\right)$ & $50-100 \%$ \\
\hline
\end{tabular}

Results are expressed as mean value \pm SD.
São Paulo, Brazil). LDL cholesterol was calculated according to Friedewald et al. [18] and LDL-oxidized was calculated according to Tsimihodimos et al [19]. Plasma glucose concentration was analysed using the enzymatic colorimetric method (Biotécnica, São Paulo, Brazil). PAI-1 and adiponectin were assessed through commercial kits (R\&D systems ${ }^{\circ}$, São Paulo, Brazil). CRP was assessed through commercial kit (Bioclin ${ }^{\circ}$, São Paulo, Brazil).

\section{Statistical analyses}

The data distribution was previously checked by the Bartlett's test for equal variances, and the data are reported as means and standard deviation. The differences in the plasma parameters among groups were accessed by unpaired $t$ test. The Pearson correlation coefficient was calculated to assess the relationship between variables. The analysis was carried out using GraphPad Prism (version 5.00) software, and the significance level was set at $\mathrm{p}<0.05$.

\section{Results}

The subjects have similar height, body mass, and body mass index (table 1). The weekly exercise intensity, frequence, volume and time experience by highly trained athletes groups are also showed in Table 1.

Table 2 show plasmatic lipid profile, glucose, PAI-1, adiponectin, and CRP levels for the two groups. Was observed less plasmatic levels the Total cholesterol $(\mathrm{p}<$ $0.001)$, LDL-c $(\mathrm{p}<0.01)$ and TG $(\mathrm{p}<0.038)$ in highly trained athletes than in sedentary group. Plasmatic PAI1 level was significantly lower $(\mathrm{p}<0.0001)$ in highly trained athletes when compared with sedentary group. The plasmatic adiponectin ( $\mathrm{p}<0.88)$, CRP $(\mathrm{p}<0.93)$, glucose $(\mathrm{p}<0.10)$, LDL-oxidized ( $\mathrm{p}<0.09)$, HDL-c $(\mathrm{p}<$ 0.32 ) concentrations and Total Cholesterol/HDL-c ratio $(\mathrm{p}<0.49)$ were not significantly different between the groups.

Table 2 Lipid profile, glucose, PAI-1, adiponectin, and CRP levels in the sedentary and highly trained athletes groups.

\begin{tabular}{lcc}
\hline Subjects & Sedentary & Highly Trained Athletes \\
\hline TG (mmol/L) & $1.40 \pm 0.62$ & $0.94 \pm 0.45^{*}$ \\
Cholesterol (mmol/L) & $3.98 \pm 0.27$ & $2.84 \pm 0.66^{* * *}$ \\
LDL-c (mmol/L) & $2.38 \pm 0.16$ & $1.50 \pm 0.80^{* *}$ \\
LDL-ox (mmol/L) & $1.37 \pm 0.67$ & $0.71 \pm 0.42$ \\
HDL-c (mmol/L) & $1.31 \pm 0.23$ & $1.15 \pm 0.35$ \\
TC/HDL-c ratio & $3.09 \pm 0.51$ & $2.72 \pm 1.28$ \\
Glucose (mmol/L) & $4.26 \pm 0.23$ & $4.45 \pm 0.06$ \\
PAl-1 (ng/mL) & $18.7 \pm 2.00$ & $4.50 \pm 1.71^{* * *}$ \\
Adiponectin (ug/L) & $14.1 \pm 3.48$ & $13.73 \pm 5.91$ \\
CRP $(\mathrm{g} / \mathrm{L})$ & $2.83 \pm 0.27$ & $2.82 \pm 0.25$ \\
\hline
\end{tabular}

Results are expressed as mean value \pm SD. ${ }^{*} p<0.05 ;{ }^{* *} p<0.01$; ${ }_{* * *} p<0.001$ significantly lower than Sedentary group. 
Was found a correlation positive between plasmatic PAI-1 and total cholesterol level $(\mathrm{r}=0.78, \mathrm{p}=0.0009)$. The plasma PAI-1 level was also positively associated with LDL-c $(\mathrm{r}=0.69, \mathrm{p}=0.006)$ and TG $(\mathrm{r}=0.56, \mathrm{p}=$ $0.03)$. All correlation is showed in Figure 1. No significant correlations were found between PAI- 1 and any other variable. No correlations were found between adiponectin and CRP with any variable $(\mathrm{p}>0.05)$. The volume and exercise frequency of the highly trained athletes group was inversely associated with TG concentration $(\mathrm{r}=-0.76$ and -0.77 , respectively; $\mathrm{p}<0.05$; data not showed).

\section{Discussion}

The results of the present study indicate that, highly trained athletes subjects that perform high amount of the exercise shown lower plasmatic lipid profile and PAI-1 levels than sedentary subjects. In addition, the plasma total cholesterol, LDL-c and TG concentration were positively correlated with pro-inflammatory PAI-1 levels.

The data of the present study confirm previous findings that subjects trained have lower plasmatic TG, LDL-c and total cholesterol concentration than sedentary subjects $[20,21]$. Tsekouras et al [22] examined the effect of high intensity intervals of aerobic training on VLDL-TG secretion in men. They observed that subjects who had trained by running on the treadmill for 8 weeks at $90 \% \mathrm{VO}_{2 \text { peak }}$ had a reduced rate of VLDLTG secretion, suggesting that subjects that perform high intensity exercise induced changes in plasmatic lipid profile. Moderate chronic exercise also induces an augment of lipase lipoprotein gene expression and activity, both in the skeletal muscle and the adipose tissue $[23,24]$, resulting in decreased plasma TG content and liver VLDL output [25,26]. Additionally, aerobic exercise increase the activity of lecithin:cholesterol aciltransferase (L-CAT), the enzyme responsible for cholesterol ester transfer to HDL-c and reduces the activity of the plasmatic cholesterol ester transfer protein (CETP), the enzyme responsible for transferring the ester in HDL cholesterol to other lipoproteins [27-31]. These alterations may lower the concentrations of total cholesterol and LDL-c in the plasma through the exchange of cholesterol ester between tissues and lipoproteins to HDL-c [32].

The plasmatic PAI-1 levels were less in highly trained athletes in relation to sedentary subjects, as showed in Table 1 . The fibriolytic system is a proteolytic enzyme system with many physiological functions of which

\section{Correlations \\ Lipid profile and PAI-1}

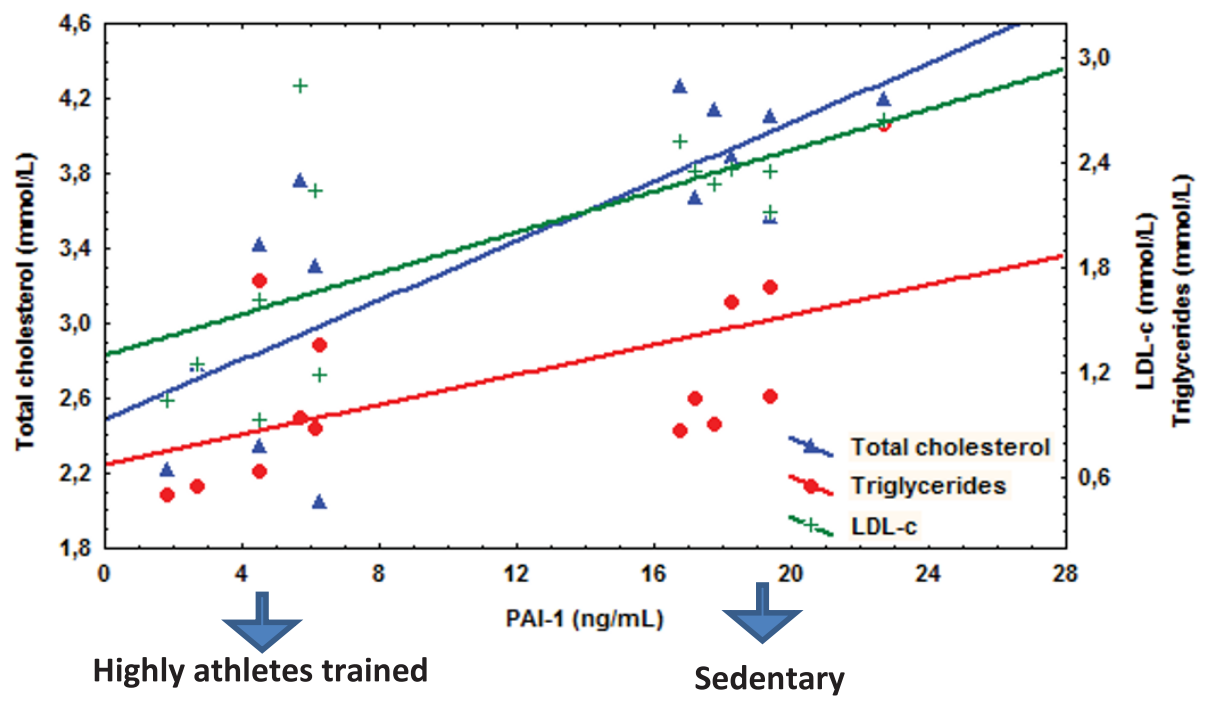

PAI-1 x CHO $r=0.78 ; p=0.001$

PAI-1 x TG $r=0.56 ; p=0.036$

PAI-1 x LDL-c $r=0.70$; $\mathrm{p}=0.006$

Figure 1 Correlation between PAI-1 and total cholesterol level, PAI-1 and LDL-c level and PAI-1 and TG level (Figure 1) 
degradation of fibrin deposits in blood vessels is the best known and possibly the most important. Studies have indicated that reduced fibrinolytic capacity, mainly due to elevated plasma levels of PAI-1, may have pathogenetic importance in myocardial infarction, particularly in patients with hypertriglyceridemia [33]. Páramo et al [4], observed a significant reduction in PAI-1 activity after aerobic regular long-term (9 months duration) indicating that exercise training had beneficial effect on fibrinolysis. Stratton et al [34] also showed that exercise training enhances fibrinolysis in healthy older men by increasing resting levels of tissue plasminogen activator and decreasing PAI-1 activity. The results of the present study indicated that high amount of exercise reduces PAI-1 levels in plasma.

Sedentary lifestyle increases the risk of developing cardiovascular disease and diabetes [1], and many other diseases which are linked to the inflammatory markers in the plasma [7]. Patients with elevated plasma cholesterol and with coronary atherosclerosis have increased plasma levels of PAI-1 [35]. Some studies indicate that this may be a consequence of the endothelial dysfunction caused by high plasma lipoprotein levels, and it is assumed that this is one of the principal causes by which these patients are at higher risk for myocardial infarctions [36]. The results of the present study comparing highly trained athletes with sedentary subjects indicates that high amount of exercise exert an important protector effect for reduced both lipid profile and PAI-1 levels.

A positive and fairly strong relationship between triglycerides, LDL, total cholesterol and PAI-1 levels in plasma is of particular interest, since it raises the possibility that hypertriglyceridemia is connected with a predisposition to thrombosis through a coexisting increase in PAI-1 concentration [33]. Jovin et al [35] related that, plasma LDL can induce an increased release of PAI-1 by endothelial cells into the vessel lumen and can contribute to the release of PAI-1 into the subendothelial space and thus to the process of atherosclerotic plaque remodelling and rupture. The significant correlations found in the present study between PAI-1 and TG, LDL and total cholesterol levels suggest that the elevated pro-inflammatory process in sedentary group may be due to the elevated values of the lipids in plasma.

In present study, no differences were verified in relation plasmatic CRP and adiponectin levels between sedentary and highly trained athletes. Changes in plasmatic CRP and adiponectin levels are more observed in weight loss interventions $[5,6,37,38]$. These data indicate that these adipokines may not be good indicators of processes linked to the increase in the lipid profile in subjects with sedentary lifestyle.

The limitations of this study include the relatively small numbers of subjects in each of the groups and the lack of subjects with cardiovascular and other diseases in which the changes in variables are assessed. Future studies should address the ability of exercise training to alter fibrinolytic variables in these groups and should also evaluate the effects of longitudinal training protocols.

In summary, our results indicate that sedentary subjects present a favourable state leading to hypertriglyceridemia and hypercholesterolemia accompanied by high PAI-1 levels. In contrast, highly trained athletes performance and high amount of the exercise reduced greatly the possibility of appearance of cardiovascular diseases.

\section{Author details}

${ }^{1}$ Department of Physiology, Division of Nutrition Physiology, Federal University of Sao Paulo, Brazil. ${ }^{2}$ Sports Science Research Group, Federal University of Alagoas, Brazil. ${ }^{3}$ Molecular Biology of the Cell Group, Institute of Biomedical Sciences, Department of Cell and Developmental Biology, University of São Paulo, Brazil. ${ }^{4}$ Department of Bioscience, Baixada Santista Campus, Federal University of São Paulo, Brazil.

\section{Authors' contributions}

FSL, JCR, AELS, HAS, ECC, MCS, ARD, LMO and RVTS participed the sample collected, assess samples, design of the study and performed the statistical analysis, and writing of paper. All authors read and approved the final manuscript

\section{Competing interests}

The authors declare that they have no competing interests.

\section{Received: 24 October 2009}

Accepted: 22 January 2010 Published: 22 January 2010

\section{References}

1. Hamburg NM, McMackin CJ, Huang AL, Shenouda SM, Widlansky ME, Schulz E, Gokce N, Ruderman NB, Keaney JF Jr, Vita JA: Physical inactivity rapidly induces insulin resistance and microvascular dysfunction in healthy volunteers. Arterioscler Thromb Vasc Biol 2007, 27(12):2650-6.

2. Eliasson M, Asplund K, Evrin PE: Regular leisure time physical activity predicts high activity of tissue plasminogen activator: The Northern Sweden MONICA Study. Int J Epidemiol 1996, 25(6):1182-8.

3. Näslund GK, Fredrikson M, Hellénius ML, de Faire U: Effect of diet and physical exercise intervention programmes on coronary heart disease risk in smoking and non-smoking men in Sweden. J Epidemiol Community Health 1996, 50(2):131-6.

4. Páramo JA, Olavide I, Barba J, Montes R, Panizo C, Muñoz MC, Rocha E: Long-term cardiac rehabilitation program favorably influences fibrinolysis and lipid concentrations in acute myocardial infarction. Haematologica 1998, 83(6):519-24

5. Milani RV, Lavie CJ, Mehra MR: Reduction in C-reactive protein through cardiac rehabilitation and exercise training. J Am Coll Cardiol 2004, 43(6):1056-61.

6. Ades PA, Savage PD, Toth MJ, Harvey-Berino J, Schneider DJ, Bunn JY, Audelin MC, Ludlow M: High-calorie-expenditure exercise: a new approach to cardiac rehabilitation for overweight coronary patients. Circulation 2009, 119(20):2650-2.

7. King $G L$ : The role of inflammatory cytokines in diabetes and its complications. J Periodontol 2008, 79:1527-34.

8. Lira FS, Koyama CH, Yamashita AS, Rosa JC, Zanchi NE, Batista ML Jr, Seelaender MC: Chronic exercise decreases cytokine production in healthy rat skeletal muscle. Cell Biochem Funct 2009, 27(7):458-61.

9. Hotamisligil GS, Shargill NS, Spiegelman BM: Adipose expression of tumor necrosis factor-alpha: direct role in obesity-linked insulin resistance. Science 1993, 259(5091):87-91.

10. Shimomura I, Funahashi T, Takahashi M, Maeda K, Kotani K, Nakamura T, Yamashita S, Miura M, Fukuda Y, Takemura K, Tokunaga K, Matsuzawa Y: 
Enhanced expression of PAl-1 in visceral fat: possible contributor to vascular disease in obesity. Nat Med 1996, 2(7):800-3.

11. Lira FS, Rosa JC, Zanchi NE, Yamashita AS, Lopes RD, Lopes AC, Batista ML $\mathrm{Jr}$, Seelaender M: Regulation of inflammation in the adipose tissue in cancer cachexia: effect of exercise. Cell Biochem Funct 2009, 27(2):71-5.

12. Arita Y, Kihara S, Ouchi N, Takahashi M, Maeda K, Miyagawa J, Hotta K, Shimomura I, Nakamura T, Miyaoka K, Kuriyama H, Nishida M, Yamashita S, Okubo K, Matsubara K, Muraguchi M, Ohmoto Y, Funahashi T, Matsuzawa Y: Paradoxical decrease of an adipose-specific protein, adiponectin, in obesity. Biochem Biophys Res Commun 1999, 257(1):79-83.

13. Hu E, Liang P, Spiegelman BM: AdipoQ is a novel adipose-specific gene dysregulated in obesity. J Biol Chem 1996, 271(18):10697-703.

14. Eliasson $M$, Evrin PE, Lundblad D: Fibrinogen and fibrinolytic variables in relation to anthropometry, lipids and blood pressure. The Northern Sweden MONICA Study. J Clin Epidemiol 1994, 47(5):513-24.

15. Syvänne M, Hilden H, Taskinen MR: Abnormal metabolism of postprandial lipoproteins in patients with non-insulin-dependent diabetes mellitus is not related to coronary artery disease. J Lipid Res 1994, 35(1):15-26.

16. Bruun JM, Helge JW, Richelsen B, Stallknecht B: Diet and exercise reduce low-grade inflammation and macrophage infiltration in adipose tissue but not in skeletal muscle in severely obese subjects. Am J Physiol Endocrinol Metab 2006, 290(5):E961-7.

17. Lohman TG: Advances in body composition assessment. Champaign. Human Kinectics Publishers 1992.

18. Friedewald WT, Levy Rl, Fredrickson DS: Estimation Of The Concentration Of LDL-Cholesterol In Plasma, Without Use Of The Ultracentrifuge. Clin Clem 1972, 18:499-502.

19. Tsimihodimos V, Gazi I, Kostara C, Tselepis AD, Elisaf M: Plasma lipoproteins and triacylglycerol are predictors of small, dense LDL particles. Lipids 2007, 42(5):403-9.

20. Teramoto M, Golding LA: Regular exercise and plasma lipid levels associated with the risk of coronary heart disease: a 20-year longitudinal study. Res Q Exerc Sport 2009, 80(2):138-45.

21. Coen PM, Flynn MG, Markofski MM, Pence BD, Hannemann RE: Adding exercise training to rosuvastatin treatment: influence on serum lipids and biomarkers of muscle and liver damage. Metabolism 2009, 58(7):1030-8

22. Tsekouras YE, Magkos F, Kellas Y, Basioukas KN, Kavouras SA, Sidossis LS: High-Intensity Interval Aerobic Training Reduces Hepatic Very LowDensity Lipoprotein-Triglyceride Secretion Rate In Men. Am J Physiol Endocrinol Metab 2008, 295(4):E851-8.

23. Seip RL, Semenkovich CF: Skeletal muscle lipoprotein lipase: molecular regulation and physiological effects in relation to exercise. Exerc Sport Sci Rev 1998, 26:191-218.

24. Magkos F, Patterson BW, Mohammed BS, Mittendorfer B: A Single 1-H Bout Of Evening Exercise Increases Basal Ffa Flux Without Affecting VLDLTriglyceride And VLDL-Apolipoprotein B-100 Kinetics In Untrained Lean Men. Am J Physiol Endocrinol Metab 2007, 292:E1568-74.

25. Mondon CE, Dolkas CB, Tobey T, et al: Causes of the triglyceride-lowering effect of exercise training in rats. J Appl Physiol 1984, 57(5):1466-71.

26. Lira FS, Tavares FL, Yamashita AS, Koyama CH, Alves MJ, Caperuto EC, Batista ML Jr, Seelaender M: Effect Of Endurance Training Upon Lipid Metabolism In The Liver Of Cachectic Tumour-Bearing Rats. Cell Biochem Funct 2008, 26:701-8.

27. Campaigne BN, Fontaine RN, Park MS, Rymaszewski ZJ: Reversal Cholesterol Transport With Acute Exercise. Med Sci Sports Exerc 1993, 25:1346-51.

28. Seip RL, Moulin P, Cocke T, Tall A, Kohrt WM, Mankowitz K, Semenkovich CF, Ostlund R, Schonfeld G: Exercise Training Decreases Plasma Cholesteryl Ester Transfer Protein. Arteriosclerosis AndThrombosis 1367, 13:1359-1993.

29. Ferguson MA, Alderson NL, Trost SG, Essig DA, Burke JR, Durstine JL: Effects Of Four Different Single Exercise Sessions On Lipids, Lipoproteins, And Lipoprotein Lipase. J Appl Physiol 1998, 85:1169-74.

30. Grandjean PW, Crouse SF, Rohack JJ: Influence Of Cholesterol Status On Blood Lipid And Lipoprotein Enzyme Responses To Aerobic Exercise. J Appl Physiol 2000, 89:472-80.

31. Durstine JL, Grandjean PW, Cox CA, Thompson PD: Lipids, Lipoproteins, And Exercise. Journal Of Cardiopulmonary Rehabilitation 2002, 22:385-98.

32. Leaf DA: The Effect Of Physical Exercise On Reverse Cholesterol Transport. Metabolism 2003, 52:950-7.
33. Stiko-Rahm A, Wiman B, Hamsten A, Nilsson J: Secretion of plasminogen activator inhibitor-1 from cultured human umbilical vein endothelial cells is induced by very low density lipoprotein. Arteriosclerosis 1990, 10(6):1067-73.

34. Stratton JR, Chandler WL, Schwartz RS, Cerqueira MD, Levy WC, Kahn SE, Larson VG, Cain KC, Beard JC, Abrass IB: Effects of physical conditioning on fibrinolytic variables and fibrinogen in young and old healthy adults. Circulation 1991, 83(5):1692-7.

35. Jovin IS, Willuweit A, Taborski U, Lehnhardt A, Schreiner K, Klövekorn WP, Müller-Berghaus $\mathrm{G}$ : Low-density lipoproteins induce the polar secretion of PAl-1 by endothelial cells in culture. Am J Hematol 2003, 73(1):66-8.

36. Kohler HP, Grant PJ: Plasminogen-activator inhibitor type 1 and coronary artery disease. N Engl J Med 2000, 342(24):1792-801.

37. Manigrasso MR, Ferroni P, Santilli F, Taraborelli T, Guagnano MT, Michetti N, Davì G: Association between circulating adiponectin and interleukin-10 levels in android obesity: effects of weight loss. J Clin Endocrinol Metab 2005, 90(10):5876-9.

38. Rokling-Andersen MH, Reseland JE, Veierød MB, Anderssen SA, Jacobs DR Jr, Urdal P, Jansson JO, Drevon CA: Effects of long-term exercise and diet intervention on plasma adipokine concentrations. Am J Clin Nutr 2007, 86(5):1293-301.

doi:10.1186/1758-5996-2-7

Cite this article as: Lira et al:: Sedentary subjects have higher PAl-1 and lipoproteins levels than highly trained athletes. Diabetology \& Metabolic Syndrome 2010 2:7.

\section{Submit your next manuscript to BioMed Central and take full advantage of:}

- Convenient online submission

- Thorough peer review

- No space constraints or color figure charges

- Immediate publication on acceptance

- Inclusion in PubMed, CAS, Scopus and Google Scholar

- Research which is freely available for redistribution

Submit your manuscript at www.biomedcentral.com/submit
Ciomed Central 